\title{
PENDUGAAN POTENSI AIR TANAH DENGAN METODE GEOLISTRIK TAHANAN JENIS KONFIGURASI SCHLUMBERGER (Jorong Tampus Kanagarian Ujung Gading Kecamatan Lembah Malintang Kabupaten Pasaman Barat, Sumatera Barat)
}

\author{
Arif Budiman $^{1}$, Delhasni ${ }^{1}$ dan S.A.H. Setyo Widjojo ${ }^{2}$ \\ ${ }^{1}$ Laboratorium Fisika Bumi Jurusan Fisika Fakultas Matematika dan Ilmu \\ Pengetahuan Alam Universitas Andalas Kampus Limau Manis Padang, Sumatera \\ Barat, 25163 e-mail: arifbudiman@fmipa.unand.ac.id. \\ 2 Dinas Pertambangan dan Energi Provinsi Sumatera Barat, Jalan Jhoni Anwar \\ No. 85 Lapai, Padang - 25142, Telp : (0751) 54487 - 52146.
}

\begin{abstract}
ABSTRAK
Penelitian untuk menentukan letak dan kedalaman akuifer air tanah telah dilakukan di Jorong Tampus Kanagarian Ujung Gading Kecamatan Lembah Malintang Kabupaten Pasaman Barat Sumatera Barat. Penelitian ini menggunakan metode geolistrik tahanan jenis dengan konfigurasi Schlumberger dengan empat titik sounding yaitu TM_01, TM_02, TM_03 dan TM_04. Jarak antar masing-masing titik sounding adalah $400 \mathrm{~m}$. Pengolahan data dilakukan dengan menggunakan software HIRA. Hasil Penelitian menunjukkan bahwa akuifer terletak pada kedalaman 96.00 100.00 m dengan titik pengeboran yang direkomendasikan terletak di titik sounding TM_03 pada kedalaman $100.00 \mathrm{~m}$. Akuifer tersebut merupakan akuifer tertekan yang terletak pada lapisan batu pasir vulkanik.
\end{abstract}

Kata kunci: akuifer, geolistrik, tahanan jenis, konfigurasi Schlumberger.

\begin{abstract}
The research to determine the location and depth of ground water aquifers has been carried out in Jorong Tampus Kanagarian Ujung Gading Kecamatan Lembah Malintang Kabupaten Pasaman Barat Sumatera Barat. This study using geoelectric resistivity method with Schlumberger configuration with a four-point soundings are TM_01, TM_02, TM_03 and TM_04. The distance between each sounding point is $200 \mathrm{~m}$. Data processing is done using software Hira. Research results indicate that the aquifer lies at a depth of $96.00-100.00 \mathrm{~m}$ with a recommended drilling point is located at the point of sounding TM_03 at a depth of $100.00 \mathrm{~m}$. Aquifer is an aquifer that lies depressed on volcanic sandstone layer.
\end{abstract}

Keywords: aquifer, geoelectrical, resistivity, Schlumberger configuration.

\section{PENDAHULUAN}

Air adalah salah satu kebutuhan dasar semua makhluk hidup terutama bagi manusia. Pertumbuhan penduduk dan kemajuan pembangunan menyebabkan meningkatnya kebutuhan akan air bersih. Sementara itu, kerusakan lingkungan dan pencemaran telah menyebabkan sumber air bersih di permukaan terus berkurang. Sebagai solusinya manusia mulai mengeksplorasi dan mengeksploitasi air bawah permukaan bumi untuk memenuhi kebutuhan terhadap air bersih.

Metode yang sering digunakan untuk menduga kondisi air bawah tanah adalah metode geolistrik tahanan jenis. Pada metode ini, arus listrik diinjeksi ke dalam bumi melalui dua 
elektroda arus, kemudian mengukur nilai tegangan dengan melalui dua elektroda potensial menggunakan alat resistivitymeter. Terdapat berbagai macam aturan yang dipakai untuk menempatkan keempat elektroda tersebut di atas. Aturan-aturan penempatan keempat elektroda tersebut dalam istilah geofisika biasa disebut dengan konfigurasi elektroda. (Hendrajaya, 1990). Meskipun terdapat berbagai macam jenis konfigurasi elektroda, tetapi yang sering dipergunakan adalah konfigurasi elektroda Wennner, Schlumberger, Dipole-dipole dan konfigurasi Rectangle. Konfigurasi elektroda Wenner dan Schlumberger digunakan dalam pelaksanaan di lapangan yang tidak terlalu sulit (cukup datar dan luas) dan penetrasi arus yang tidak terlalu dalam (Hendrajaya, 1990). Sedangkan untuk bentangan yang tidak merata serta penetrasi arus yang dalam maka digunakanlah konfigurasi elektroda Dipole-dipole. Konfigurasi elektroda Rectangle sangat jarang digunakan karena pengaturannya yang sedikit sulit.

Kenagarian Ujung Gading Kecamatan Lembah Malintang Kabupaten Pasaman Barat Sumatera Barat merupakan salah satu daerah yang penduduknya mengalami kesulitan dalam memperoleh air bersih. Pada daerah tersebut penduduknya memanfaatkan air sungai yang kebersihannya belum terjamin. Pada musim kemarau sungai-sungai ini mengalami kekeringan. Oleh karena itu, di daerah ini perlu dilakukan penelitian dalam upaya pencarian sumber air tanah guna memenuhi kebutuhan masyarakat terhadap air bersih.

Penelitian ini hanya dilakukan pada satu jorong yaitu Jorong Tampus, yang terdiri dari 4 buah titik sounding, dimana jarak antar titik sounding adalah 200 meter. Dalam penelitian ini digunakan metoda geolistrik tahanan jenis konfigurasi Schlumberger. Konfigurasi ini merupakan konfigurasi yang paling banyak digunakan dalam pencarian sumber air tanah karena penetrasi arusnya lebih dalam dan cara kerjanya lebih mudah. Dalam pengolahan datanya digunakan Software HIRA.

Tujuan dari penelitian ini adalah untuk melakukan interpretasi data geolistrik yang telah diperoleh, sehingga letak dan kedalaman air tanah dapat ditentukan. Hasil penelitian ini diharapkan dapat memberikan informasi tentang letak dan kedalaman akuifer air tanah dalam upaya pembuatan sumur air bersih pada daerah tersebut, sehingga yang diharapkan masyarakat di Jorong Tampus Kenagarian Ujung Gading Kecamatan Lembah Malintang Kabupaten Pasaman Barat, Sumatera Barat dapat menggunakan air tanah sebagai salah satu sumber air dan menjadi solusi ketersediaan air.

\section{METODOLOGI}

Alat

Adapun alat-alat yang digunakan dalam penelitian ini adalah:

1. NANIURA Resistivity Meter Model NRD $22 \mathbf{S}$, yang merupakan alat utama yang digunakan dalam penelitian geolistrik ini (Gambar 1.a).

2. Dua pasang elektroda yang terdiri dari sepasang elektroda potensial M-N dan sepasang elektroda arus A-B (Gambar 1.b).

3. Kabel untuk penghantar arus dan tegangan (Gambar 1.c).

4. Aki basah yang digunakan sebagai sumber tegangan (Gambar 1.d).

5. Palu digunakan sebagai alat bantu untuk memancang elektroda pada tanah (Gambar 1.e).

6. Meteran digunakan untuk alat ukur jarak elektroda (Gambar 1.f). 


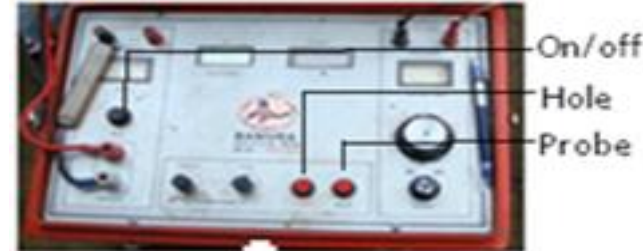

a

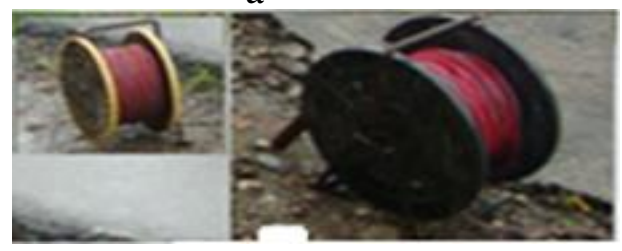

c

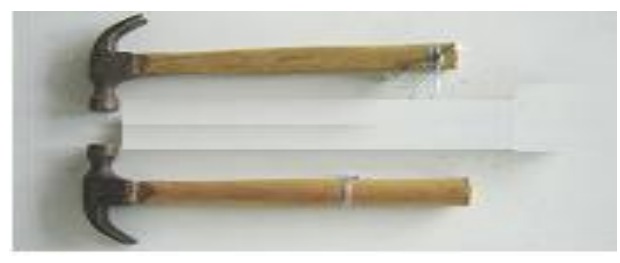

e

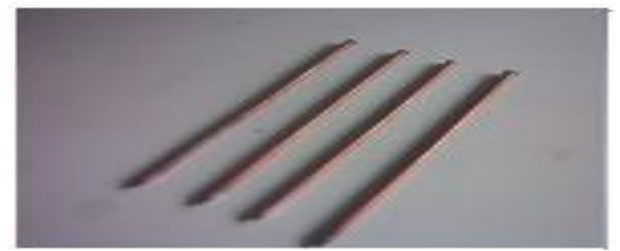

b

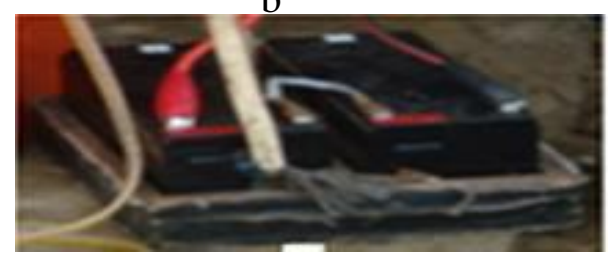

d

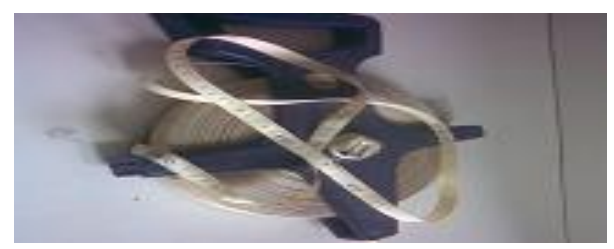

f

Gambar 1. Peralatan penelitian (a) Naniura Resistivitymeter, (b) Elektroda, (c) Kabel, (d) Aki, (e) Palu dan (f) Meteran.

\section{Tata Laksana Penelitian}

\section{Pengambilan Data}

Penelitian ini menggunakan konfigurasi Schlumberger dengan empat titik sounding (TM01, TM02, TM03,dan TM04 . Bentang maksimum untuk satu titik sounding adalah 200 meter, seperti yang terlihat pada (Gambar 2). Jarak elektroda arus $(A B / 2)$ mulaidari 1 sampai 200 meter dan jarak elektroda potensial (MN/2) mulai dari 0,5 sampai 25 meter.

\section{Pengolahan Data}

Pengolahan data dapat dilakukan dengan komputer menggunakan software HIRA. Dimana software ini merupakan program yang dibuat untuk menghitung nilai resistivitas dari hasil perhitungan di lapangan. Dengan memasukkan data yang ada yaitu nilai arus dan beda potensial dapat diperoleh nilai resitivitas dan ketebalan atau kedalaman masingmasing lapisan.

\section{Interpretasi Data}

Interpretasi data dapat dilihat dengan membaca hasil kurva sounding yang terdapat pada software HIRA. Pertama menentukan letak dan kedalaman akuifer, dilanjutkan menganalisis berdasarkan informasi geologi yang ada pada literatur dengan menggunakan data nilai-nilai resistivitasnya serta membuat penampang pemetaan dari gabungan titik sounding penelitian. 


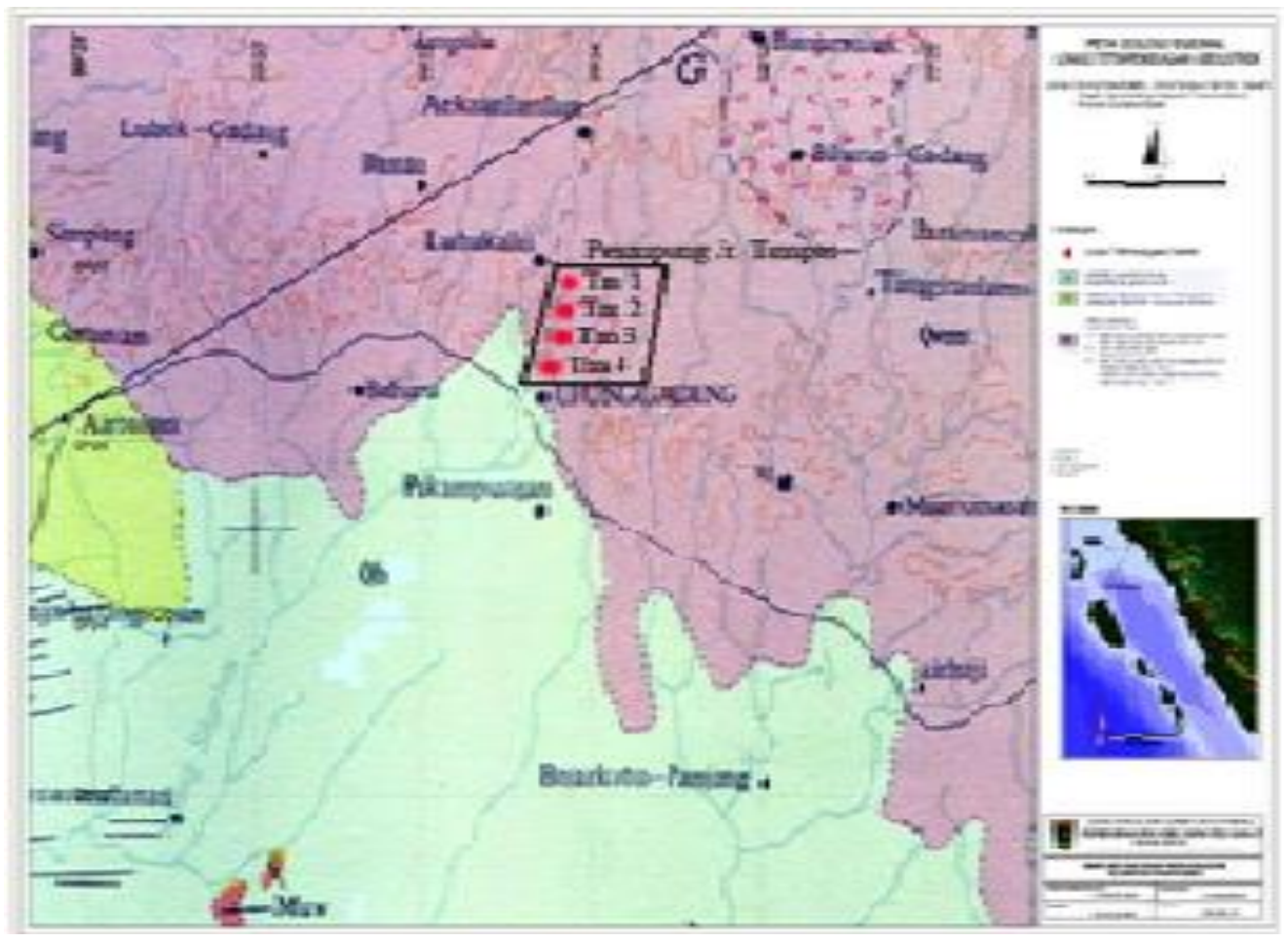

Gambar 2. Lokasi titik sounding penelitian di Jorong Tampus Kanagarian Ujung Gading (Silitonga dan Kastowo, 1975).

\section{HASIL DAN DISKUSI}

Dari informasi geologi, urutan satuan stratigrafi Kanagarian Ujung Gading Kecamatan Lembah Malintang Kabupaten Pasaman Barat Sumatera Barat terdiri dari batuan sedimen dan vulkanik. Batuan sedimen terdiri dari dengan formasi alluvium $(\mathrm{Qh})$ dan formasi air balam (QTa). Pada formasi alluvium terdapat lapisan batupasir, lapisan kerikil dan lapisan lempung dan pada formasi air balam terdapat lapisan batu lempung dan lapisan batu lempung pasiran. Batuan vulkanik terdiri dari formasi pusat melintang (Qvmt) yang terdapat lapisan lahar andesitik sampai dasitik, breksi gunung api dan lava. Keempat titik sounding berada pada formasi pusat melintang (Silitonga dan Kastowo, 1975). Pada zona pelapukan basalt, batuan vulkanik (dari blok sampai debu vulkanik) terdiri dari batuan lepas pasir, kerikil dan lempung pasiran. Breksi vulkanik dan truf batu apung terdiri dari batuan kompak seperti breksi konglomerat, batu pasir dan batuan karbonat yaitu batu gamping politik. Basalt, andesit, riolit terdiri dari batuan karbonat yaitu batu gamping dolomit dan batu gamping non dolomit (Wurtanto, 2007).

Dengan menganalisis hasil pengolahan data dan keadaan geologi yang mengontrol daerah setempat sebagaimana yang diterangkan di atas diduga lapisan pada masing-masing titik sounding terdiri dari empat lapisan. Selanjutnya, untuk mendapatkan bentuk perlapisan yang maksimal di sepanjang lintasan daerah penelitian maka dibuat penampang dua dimensi berdasarkan nilai $h$ (ketebalan) dan $\rho$ dapat dilihat pada Gambar 3. 


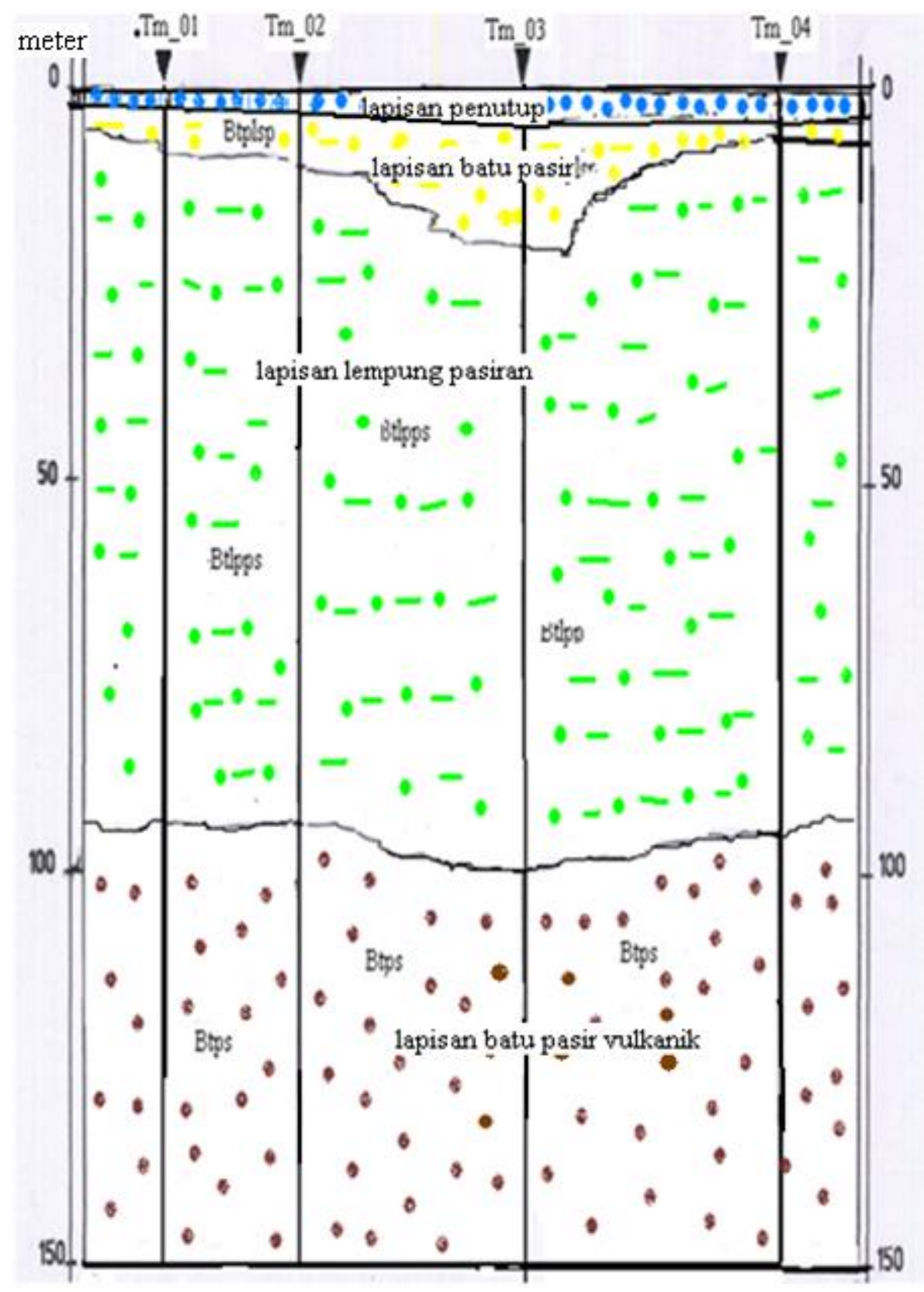

Gambar 3. Penampang dua dimensi penggabungan titik-titik sounding.

Secara keseluruhan lapisan - lapisan batuan di sepanjang lintasan gabungan titik sounding tersebut adalah :

1. Lapisan pertama dengan ketebalan 1,00 - 1,55 meter dengan nilai tahanan jenis 84,00 hingga $200,00 \Omega \mathrm{m}$, diinterpretasikan sebagai lapisan tanah penutup.

2. Lapisan kedua dengan ketebalan lapisan 2,30 - 4,15 meter dengan nilai tahanan jenis $311,00-610,00 \Omega \mathrm{m}$, diinterpretasikan sebagai lapisan batu pasir.

3. Lapisan ketiga dengan ketebalan lapisan 90,50 - 95,40 meter dengan nilai tahanan jenis $6,48-154,00 \Omega \mathrm{m}$, diinterpretasikan sebagai lapisan lempung pasiran. 
4. Lapisan keempat dengan ketebalan lapisan tak hingga dengan nilai tahanan jenis 42.92 - $383.00 \Omega \mathrm{m}$ diinterpretasikan sebagai lapisan batu pasir vulkanik.

Akuifer tertekan (confined aquifer) terletak di bawah lapisan kedap air (impermeable) dan mempunyai tekanan lebih besar daripada tekanan atmosfer. Air akan mengalir pada lapisan pembatasnya, karena akuifer tertekan merupakan akuifer yang jenuh air yang dibatasi oleh lapisan atas dan bawahnya (Aryono, 2003). Lapisan lempung pasiran mempunyai kerapatan porositas yang tinggi yaitu $45-55 \%$, sehingga tidak dapat meloloskan air. Lapisan batu pasir vulkanik yang terletak di bawah lapisan lempung pasiran dengan kerapatan porositas yaitu 10-20\% (Sosrodarsono. 2006). Jadi lapisan ini dapat meloloskan air dan air yang melewatinya dapat ditampung. Sehingga dapat disimpulkan yang merupakan lapisan akuifer diduga terletak pada lapisan keempat yaitu lapisan batu pasir vulkanik yang merupakan akuifer tertekan.

Tabel 1. Kedalaman akuifer tertekan pada masing- masing titik sounding.

\begin{tabular}{|c|c|}
\hline No.Titik Sounding & Kedalaman Akuifer Tertekan (m) \\
\hline TM-01 & 96.50 \\
\hline TM-02 & 94.00 \\
\hline TM-03 & 100.00 \\
\hline TM-04 & 95.00 \\
\hline
\end{tabular}

Kedalaman masing-masing akuifer tertekan pada lapisan keempat untuk masing-masing titik sounding dapat dilihat pada Tabel 1. Berdasarkan hasil diatas maka dapat kita tentukan di titik sounding mana yang cocok nantinya untuk dilakukan pengeboran. Berdasarkan tata cara eksplorasi pengeboran air tanah yang baik yaitu untuk satu penampang hanya diperbolehkan satu titik pengeboran agar tidak merusak lingkungan. Jika ditinjau dari segi ekonomis, maka titik sounding TM-02 yang paling murah biaya pengeborannya, karena paling dangkal dibandingkan titik-titik yang lainnya. Jika ditinjau dari tata cara eksplorasi pengeboran air tanah yang baik, titik yang layak untuk dilakukan pengeboran adalah titik sounding TM-03 dengan kedalaman pengeboran $100 \mathrm{~m}$, pada titik ini letak akuifer tertekannya paling dalam karena pada titik ini letak akuifer tertekannya paling dalam. Jika dilakukan pengeboran di titik lain akan merusak lapisan. Karena dilakukan penyedotan air ke permukaan maka air akan naik dalam jumlah banyak, dalam lapisan yang paling dalam banyak mengandung air. Jika dilakukan penyedotan di titik yang dangkal maka akan terjadi pemaksaan pada air tanah sehingga akan merusak pori-pori tanah.

\section{KESIMPULAN}

Dari penelitian ini dapat diperoleh beberapa kesimpulan yaitu:

1. Berdasakan hasil interpretasi data, daerah penelitian terdiri atas empat lapisan yaitu lapisan tanah penutup, lapisan batu pasir, lapisan lempung pasiran dan lapisan batu pasir vulkanik.

2. Jenis akuifer yang terdapat pada daerah penelitian ini diduga akuifer tertekan yaitu terletak pada lapisan batu pasir vulkanik. 
3. Berdasarkan tata cara eksplorasi pengeboran air tanah yang baik, titik sounding yang layak untuk dieksplorasi pada penelitian ini yaitu titik TM-03 dengan kedalaman pengeboran $100 \mathrm{~m}$.

\section{DAFTAR PUSTAKA}

1. Aryono, A.M. 2003. Metode Geofisika. Universitas Negeri Semarang, Semarang.

2. Hendrajaya. 1990. Metode Geofisika. Semarang: Universitas Negeri Semarang.

3. Silitonga dan Kastowo. 1975. Peta Geologi Lubuk Sikaping. Padang: Badan Pusat Statistik kota Padang.

4. Sosrodarsono. 2006. Penentuan Lapisan Batuan dengan Metoda Geolistrik. Penerbit Erlangga, Jakarta.

5. Wurtanto. 2007. Aplikasi Metode Geolistrik Tahanan Jenis Menentukan Kedalaman Akuifer Air Tanah Menggunakan Konfigurasi Schlumberger. Universitas Semarang, Semarang 